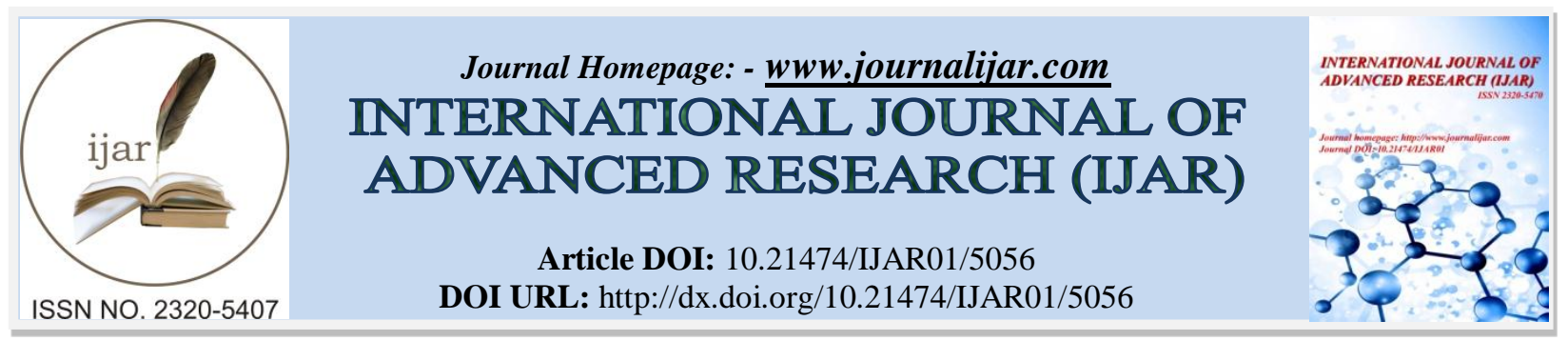

RESEARCH ARTICLE

\title{
FASTING - A REMEDY FOR HEALTHY LIVING.
}

Dr. Smita Vinod Zambare ${ }^{1}$, Dr. Dnyaneshwar Jadhav ${ }^{2}$ and Dr. Shilpa prakash yerme ${ }^{3}$.

1. M. D (Ayurved), Assistant Professor, Swasthvritta Dept, Shri Dhanvantari Ayurved College, Mathura, India.

2. M.D (Ayurved), Assistant Professor, Kaychikitsa Dept, Shri Dhanvantari Ayurved College, Mathura, India.

3. M.D (Ayurved), Professor \& HOD Kriyasharir dept, S. G. R. Ayurved College, Solapur, India.

\section{Manuscript Info}

Manuscript History

Received: 03 June 2017

Final Accepted: 05 July 2017

Published: August 2017

Key words:-

Fasting ,Ayurved, Naturopathy, Healthy Living

\begin{abstract}
Nature cure believes that the cause of diseases is the accumulation of toxins in the body. Fasting is new natural and wonderful way of life.If one wantto be healthy, disease free, cheerful and joyous, this natural way is to be cultivated byyou without any loss of time. Fasting promotes, restores and maintains good health, eliminates pain , misery and very helpful in weight control and prolongs life.Fasting every day for few hours take less, light, natural food which is positive in nature helps to cure the destructive diseases.
\end{abstract}

Copy Right, IJAR, 2017,. All rights reserved.

\section{Introduction:-}

Fasting is a religious vow that makes us feel mentally satisfied and psychologically relaxed besides physical well being, if properly observed. We have seen our forefathers going on fast on certain religious occasions such as Ekadashi, Shivaratri,Janmasthami,Chaturthi etc. but at the same time we also saw some of them enjoying some tasty dishes on fasting days, which defeats the very meaning of actual fasting. It shows that, though we know what fasting is, but we do not understand the meaning of fasting. Fasting is voluntary abstinence from taking any type of food for definite time in order to give rest to digestive system. During Fasting, the body eliminates the toxins and morbid matters accumulated in the body, with a greater speed. Fasting is nothing but a new way of life, so it is important to understand about fasting in detail.

\section{Concept of Fasting According to Naturopathy:-}

Fasting is not merely avoiding intake of food for a particular period and taking little water as per requirement of our body to support on the stored reserves within the tissues, but it also involves Sunbaths, Rest, Mental peace and Physical Care during the recuperation, once the fast is broken. Fasting may turn into starvation if refraining from food is continued beyond the period of sustainability on stored reserves in the body, due to its drop down to a dangerously low level. Generally, Fasting does cause death unless it is allowed to reach the level of starvation, at the same time Fasting is not another form of Feasting as well. It requires knowledge and experience to get desired benefits from Fasting. 1

Fasting can be of different durations such as short Fasting for three to seven days, long Fasting from ten to sixty days. When the Fasting is done for more than two weeks, then eliminatory diet is taken in the middle of the Fasting duration before under taking another Fast. 


\section{Reasons for Fasting:-}

Fasting can prolong human life by resulting in many of the health related benefits such as helping in weight control as well as eliminating pain misery to restore and maintain good health. In our modern lifestyle where living on brain work has tremendously reduced the physical labor, our need for food is also reduced, but due to increased production, artificially increased palatability and increased income, the people have developed the habit of taking junk foods and unnecessary food consumption resulting in putting up extra weight and undesired fats.

For such cases Fasting can be the quickest, safest and most effective tool for weight management. As a method for weight control, Fasting has the following basic advantages over the process of physical exercise:

$>$ Free and relaxed breathing is experienced.

$>$ Comfortable and easy body movements.

$>$ No fatigue and tiredness.

$>$ Sense of heaviness and discomfort in the abdomen disappears.

$>$ No irritation from digestion is felt.

$>$ Comparatively lighter load on heart due to lower blood pressure.

Even if you resort to exercise for weight control, you need to practice Fasting parallally, since exercise increases appetite and results in slow reduction or no reduction in weight. To lose one pound of weight we need work as hard as chopping would for ten to eleven hours or riding horse for 43 miles, which is not possible for everyone due to constraint of time. But one can lose up to 20 pounds per week in initial periods of long Fasts. Besides securing physiological rest for digestive, glandular, circulatory, respiratory and nervous system, fasting conserves energy of the body which is generally consumed in the work of digestion process and permits its diversion to other channels.Fasting results in quick purification of blood stream.

Body liquidates its non-essential tissues during the long Fast and uses them as nutrients for sustaining essential tissues. Also the accumulated toxins are released into blood and lymph which are further carried to the organs of excretion for expelling out from the body. After a Fast, less food is required to maintain physical energy, physiological activity, nitrogen balance weight, since it produces a more efficient physiological mechanism. ${ }^{2}$

This is the reason that a lean person under various weight gaining diets generally finds that after fasting he gains weight on much less foods than what he has been in habit of taking.

\section{Types of Fasting:-}

a. According to duration:-

i. Short duration -2 to 5 days

ii. Intermittent -1 to 2 days

iii. Long duration - more than 10 days. ${ }^{3}$

b. According to methods of Fasting:

i. Dry fasting - without drinking even water

ii. Water Fasting - only with water

iii. Juice Fasting - consuming only juices

iv. Fruit Fasting - eating only fruits

v. Mono diet Fasting - by eating single type of food. ${ }^{4}$

c. According to condition of Faster:

i. Fasting by healthy person

ii. Fasting in acute illness.

iii. Fasting in chronic illness- Short Fast (3-5 days) is indicated with proper intervals. Positive food is given during breaks in the Fast.

\section{Ideal Situations for Fasting:-}

Right Time:-

Though Fasting is equally beneficial at all the times of the year, the thumb rule for Fasting says "Fast when there is a need for it". Fasting gives positive results but it takes time to develop the visible results. Therefore while starting Fasting, do not expect miraculous development and instant recovery. 


\section{Right Place:-}

Though the most favorable place for Fasting should be his/ her home, but the emotional influence and inevitable opposition from the family members, relatives, neighbors and well wishers become the greatest obstacle to Fasting at home. Worried about his health sometimes they even quarrel with the Faster and annoy him so much that Fasting becomes difficult. Some of them may go to the extent of calling a physician to persuade him to break the Fast.

\section{Right Atmosphere:-}

The right atmosphere for Fasting is quite and peaceful surrounding, where the ambient air is pure, water is uncontaminated and people are congenial. Therefore, the most ideal place for Fasting is a professional institution where Fasting is regularly carried out. In such institutions the Fast can be supervised by the experienced experts. The experts will explain the Faster specific objective of his Fast such as whether it is to reduce weight, manage blood pressure, relieve the body from accumulated wastes or to relax the tired nervous system or any other specific reason for the individual Faster. The Faster is kept under constant observation and close watch and he breaks the Fast when his objective is attained. In case of any discomfort or danger to Faster, the Fast can be terminated before time.

\section{Ideal Duration for Fasting:-}

Fast should be broken only when the hunger returns. On return of hunger it sweetens the breath, clears the tongue a clean taste is experienced by mouth, giving a clear indication that the body has completed the work of cleansing and now it is ready to reserve eating. Most Fasts are broken before return of hunger for the reasons beingFaster getting too thin or feeling weakness, lake of time or funds, anxiety to end Fast as soon as annoying symptoms disappear. At times, results of premature breaking of Fasts are disappointing and make the difference between complete success and partial failure.

\section{Fundamentals of Fasting: 5}

i. Preparation: First of all clear your mind of all the fears about Fasting. Accept the fact that Fasting is a normal process that will be highly beneficial to your health. Start it without any fear or anxiety.

ii. Rest: Nature automatically conserves on one side to expand on other side. So minimize physical, mental and sensory activities.

iii. Activity: If the objective of Fasting is weight reduction, then carry out some moderate exercise under supervision of experts.

iv. Warmth: Due to lower resistance to cold, the Fasters tend to chill. To maintain body temperature, keep warm, particularly at the feet.

v. Water: Avoid eating Ice or Ice cream. Drink plain water only if necessary. Drinking warm water will be more beneficial.

vi. Bathing: As per need, take bath once or twice daily but avoid long stay under the water. It may cause chilling. In case of weakness you may take sponge bath also.

vii. Sunbathing: Take sunbath preferably in the morning by exposing front and back for at least five minutes each. Gradually increase the duration of exposure by one minute every day. Ten minute exposure is sufficient.

viii. $\quad$ Purges: No purges or anemia, except under the expert's supervision only if very much necessary.

ix. $\quad$ Suffering / Illness: Fasting is more beneficial when you are not well.

\section{Precautions to be Observed, During and after the Fast is Broken: ${ }^{6}$}

1. Supervision of experienced experts is must for any Fast for the duration of more than three days. It should be done at quite and peaceful surrounding, where the ambient air is pure, water is uncontaminated and people are congenial.

2. Wear loose cotton cloths. Use natural substitutes for artificial and processed things like terylene cloths, mosquito curtains, tooth pastes and brush etc.

3. Feel comfortable by placing your feet in north direction While sleeping, to keep your body in tune with magnetic field.

4. Sleep in a well ventilated room without covering your face and nose.

5. If the Faster feels hungry, he should drink water during the breaks in the Fasting.

6. Conserve energy for quick healing. So avoid hearing radio, watching television, movies or excessive reading to conserve energy. 
7. Sometimes certain physical developments during Fasting, such as, tongue coating heavily, bad taste in mouth, bad odors in breath, teeth becoming pasty as if in fever, dark and foul urine etc create panic in the Fasters, as if your illness getting worse. But in fact the whole procedure indicates that the body is throwing out the unwanted toxins and morbid wastes accumulated.

8. Do not rush to laxatives and anemia if you do not get motion during Fasting. The bowel will get cleared after sometime automatically. In case of nausea and vomiting, take water mixed with honey or orange.

9. In case of rashes/swelling or cracks on the skin, do not use any ointment. Just clean with water.

10. Do not start walking immediately after getting up in the morning. Do it slowly in relaxed manner.

11. External treatment mud packs, hydro therapy etc to be stopped during Fasting.

12. Keep away from bad habits such as smoking, drinking, tobacco chewing etc.

13. Control your emotions and take complete rest during Fasting.

14. Practice corpse pose (shavasan) and entertainment music, light reading or practice meditation while lying down.

15. After Fasting, for a week or two, take eliminative diet like coconut water, fruit juice, vegetable soup, diluted butter milk, then slowly move on to restricted diet for some time and then resort to normal diet.

\section{Signs of Elimination of Toxins during Fasting:}

i. Formation of gas due to disintegration of old putrefied matters.

ii. Cotton mouth and expulsion of morbid matters in mouth.

iii. Bad breath due to expulsion of morbid matters through respiratory tract.

iv. Coated tongue due to deposition of eliminated toxins.

v. Elevated body temperature in first few days.

vi. Offensive perspiration due to expulsion of morbid matter. ${ }^{7}$

\section{Benefits of Fasting:-}

a. The body becomes free from the deposited toxins and filth.

b. It is very useful in curing many diseases especially obesity, gastroenteritis, indigestion, fever etc.

c. Fasting is an excellent remedy for physical, mental and spiritual development.

d. It is the "Prayaschitta "lesson for bad eating habits against the divine laws of health. ${ }^{8}$

e. In modern era, life style disorders are increasingandwith the fasting we can reduce the extra weight, that helps to cure the life style diseases

\section{Exercise and Yoga:-}

Exercise is advisable for 30 to 60 minutes everyday, when the fasting period is over.

Brisk walking for $2-4 \mathrm{~km}$ in the morning before breakfast is advisable.

Abdominal exercises are advised.

Engagein household works like sweeping washing clothes, dusting the furniture and gardening.

Yoga for 30 minutes is advised after the fasting periodis over

General Asanas- Omkar chanting, chanting mantras, Yogmudra, Kapalbhati, suryanadi (breathing through right nostril),deep breathing, anuloma-vilomapranayam,Bhujangasana, suryanamaskar, shalabhasan, Vakrasana, Pavanmuktasana, Halasana, Sarvangasana, paschimottanasana, Dhanurasana, are recommended after the Fasting is over. ${ }^{9}$

\section{Fasting According to Ayurveda:-}

Ayurveda says "langhanamparamaushadham". Fasting which is similar to "Shudhanigrah" which is one of the 10 types of "Langhanchikitsa" in Ayurveda."

It is also known as "Apatarpanchikitsa". In this, Tej,Vayu\&Aakashmahabhootare involved. Fasting is one of the type of shaman chikitsa. ${ }^{11}$

Body feels lighter after "Langhan Therapy". All the vitilateddoshas and toxins are eliminated through "Langhan". Some diseases which are in early stage are overcome by this "langhan" therapywhich is called as Shaman chikitsa. $^{12}$

According to Ayurveda "Kshudhanighrah" that is "Upawas"(fasting) is abstaining from food intake even while feeling hungry. Some diseases are cured by Upawasspeciually in the persons those having alpa bala. ${ }^{13}$ This is of 2 types. 


\section{1) Anashan:-}

In this type of Fasting no food is advised even whenone feels hungry. This type of Fasting is prescribed in the event of digestive disorders like indigestion, aamajvyadhi like aamvaat.

2) Laghavshan:-

In this type of Fasting, small servings of foodis advised, which is close to nature \& light to digest. This type is prescribedin all types of fever, Diabetes,obesity \&life style related disease.

\section{Conclusion:-}

Different system of medicine describe importance of Fasting in different words, but result and aim is same. Ultimately Fasting has own importance in natural way curing the disease.

\section{References:-}

1. Fasting, Diet \& Treatment, Author Dr Jaynarayan Jayswal, Gopal Granthgrih Prakashan, Kothrud, Pune $1^{\text {st }}$ Edition 1991 chapter 17, page no-91, 94.

2. Efficacy of Fasting, author Dr Dhiren Gala, Dr Sanjay Gala, Navneet Publications India Ltd,Dantali,Gujarat. Chapter 4, page no-16 to 19.

3. SvasthavrittaVigyan, author Dr Sarvesh Kumar Agrawal, Chaukhamba Orientalia Prakashan, Varanasi, edition 2011, Paper 2 part A, chapter 2, page no-407

4. Textbook of Svasthavritta, author Dr.MangalagowriRao, Chaukhamba Orientalia Prakashan, Varanasi, edition 2011, Paper 2, part A, chapter 15, page no-479.

5. Fasting, Diet \& Treatment, Author Dr Jaynarayan Jayswal, Gopal Granthgrih Prakashan, Kothrud, Pune $1^{\text {st }}$ Edition 1991 chapter 17, page no-97.

6. Fasting, Diet \& Treatment, Author Dr Jaynarayan Jayswal, Gopal Granthgrih Prakashan, Kothrud, Pune $1^{\text {st }}$ Edition 1991 chapter 17, page no-99.

7. Textbook of Svasthavritta, Dr Mangalagowri Rao, Chaukhamba Orientalia Prakashan, Varanasi, edition 2011, Paper 2, part A, chapter 15, page no-481.

8. SvasthavrittaVigyan, author Dr Sarvesh Kumar Agrawal, ChaukhambaOrientaliaPrakashan, Varanasi, edition 2011, Paper 2 part A, chapter 2, page no-408

9. Nature Cure for All- Nature Remedies for Health Disorders, Published by Nisargopachar Ashram \& Trust, Uralikanchan, Pune in July 2007, chapter 1.2, page no-19, 20.

10. Charaksamhita, charakchandrika- hindi commentary by Dr.Brahmanand Tripathi\& Dr.Gangasahay Pandey, Chaukhamba subharati Prakashan, edition 1995, sutra-Sthana, chapter-22, sutr-18, page no-414.

11. SarthaVagbhat- Ashtanghruday Marathi translation by Dr.Ganesh K Garde, Raghuvanshi prakasha,Pune $2,8^{\text {th }}$ edition, 1996, sutra-sthana, chapter 14 sutra 2,4,6 \& 7, page no-63,64.

12. Kaychikitsa Part-1, by Vd.Praffula \& Vd.Sadhana Babel, VdShivaji wavhal, Shantanu Prakashan, $3^{\text {rd }}$ edition October 2009., chapter5, page no-205,206

13. Charaksamhita, CharakChandrika- hindi commentary by Dr.Brahmanand Tripathi \& Dr.Gangasahay Pandey, Chaukhamba subharati Prakashan, edition 1995, sutrasthana, chapter 22, sutra 22, page no-416. 